\title{
An Investigation of the Interaction Markers of Pakistani Journalistic Discourse from Gender Perspective
}

\author{
Muhammad Mehboob-Ul-Hassan ${ }^{1}$, Fahmeeda Gulnaz ${ }^{2}$, Haroon Shafique ${ }^{1} \&$ Muhammad Adrees $^{3}$ \\ ${ }^{1}$ Department of English, University of Lahore Gujrat Campus, Pakistan \\ ${ }^{2}$ Department of English, Taif University, Saudi Arabia \\ ${ }^{3}$ Department of Business, Mirpur University of Science and Technology, Pakistan \\ Correspondence: Muhammad Mehboob-Ul-Hassan, Department of English, University of Lahore Gujrat Campus, \\ Pakistan. E-mail: m.mehboob300@yahoo.com
}

Received: October 30, 2018 Accepted: January 15, 2019 Online Published: February 24, 2019

doi:10.5539/ijel.v9n2p153ＵRL: https://doi.org/10.5539/ijel.v9n2p153

\begin{abstract}
The objective of this research is to investigate the language used by male and female Pakistani journalists by focusing on the use of interaction markers. This study aims to explore the meta-discourse features in the writings of the Pakistani English newspaper journalists. The data is collected from Dawn, The News, The Nation and The Express Tribune newspapers. The corpus for the research consisted of two hundred (200) columns written by forty Pakistani journalists including both males and females. Hyland's (2005a) model of interactional meta-discourse was used as a theoretical framework. Mixed methodology will be used to analyze the data qualitatively and quantitatively to find out the gender-based differences in the use of interaction markers in the writings of Pakistani journalists. First, the data collected are quantified quantitatively then for the elaboration of gender-based differences in the use of interaction markers, qualitative research methodology is used. Moreover, Antconc, a corpus-based research tool, is employed to statistically analyze the corpus of the study. The study provides the analysis of interactional markers in the Pakistani journalistic discourse by employing Hyland's (2005a) model of interaction. The results show that there exists a gender-based difference in the use of interaction markers. The female Pakistani columnists use interaction markers more frequently than the male counterparts. The research provides new insight to the national and international researchers about gender-based differences in media discourse within the Pakistani context.
\end{abstract}

Keywords: gender differences, interaction markers, journalistic discourse, male journalists, female journalists

\section{Introduction}

The phenomenon that men use language differently from women has been studied for many years. In fact, language is not only a source of communication but also a source to show power and supremacy over others. In the past, most of the works on language were related to male language. Labov (1972a) mostly worked on the conversations of men. Later, the linguists started to work on gender differences. The differences were limited to grammatical ones like morphological differences. The work started by Lakoff (1975) set new trends in the field of sociolinguists to highlight the areas where men and women differ in language use. She analyzed the language and linguistics code as a source to identify the gender of the speaker or writer. She raised questions: Do women use more adjectives than men? Do women leave their sentences incomplete? Do females have restricted or limited vocabulary than their counterparts? These questions motivated other linguistic to work on gender-based differences in the use of language by men and women.

Similarly, Tannen (1990) highlights six differences in the use of language used by men and women. The difference of status and support claims that men live in a world where conversation is for dominance and competition. They use language to gain the upper hand or to dominate others. Women talk to gain affection, confirmation and support for their opinion and ideas. For men, the world is a place where people strive to maintain their status. For women, the world is a place of connections to seek support, affection, confirmation and consensus. Women think of support, affection and intimacy. Men are concerned with power, status and independence. For these reasons, men and women use language differently.

The difference of complaint and sympathy claims that males take a complaint as a challenge to achieve. For 
females, a challenge is tackled with sympathetic words. Historically, men are seen to be concerned with important issues, whereas women are concerned with trivial matters, sharing family matters and emotions. Similarly, women use words which show that people do things indirectly while men use words as direct imperatives. The situation of conflict and compromise is seen during work. Where management orders look unattractive, males oppose them vocally while women try to accede.

Discourse analysis is not concerned with the grammatical aspects of a sentence rather it manipulates different discursive formations (Fairclough, 1992). Discourse analysis is a system of rules according to which statements in different situations and contexts are analyzed. For journalistic data, discourse analysis is important as it makes different approaches to meta-discourse analysis more explicit. The link between speaker and listener is manifested by discourse in different ways. For example, to keep distance from the readers, words or passivized words may be seen in written tasks. Interaction markers focus on the participants and display the writer's individuality with the traditions of a community (Hyland, 2010). Interaction markers comprise of stance markers and engagement markers. These are subcategorized. Hedges, boosters, self-mentions and attitude markers are the subcategories of stance markers. Reader pronouns, questions, knowledge reference, directives and personal asides are the kinds of engagement markers. We can examine interaction markers in different genres and contexts.

Interaction markers are an important part of all kind of writings as they highlight the knowledge of the writers about the community. Such interactional devices help the authors to highlight their authority in the academic world (Rahimivanda, 2014). Another important quality of discourse is manifested by the use of interactional markers by which the writers change their tone, stress what they think and present a suitable friendly attitude to the listeners and readers.

Interaction markers focus on the participants and display the writer's individuality with the traditions of a community (Hyland, 2010). Interaction markers comprise of stance markers and engagement markers. These are subcategorized as hedges, boosters, self-mentions and attitude markers are the subcategories of stance markers. Reader pronouns, questions, knowledge reference, directives and personal asides are the kinds of engagement markers. Adel (2006) improved and changed the taxonomies of meta-discourse. The present taxonomies of meta-discourse are developed by Hyland and Tse (2004). These depict the division of meta-discourse markers as interactive and interactional recourses. Transitions, code gloss, evidential and frame markers are interactive markers while hedges, boosters, self-mentions, attitude markers and engagement markers are interactional markers. In the use of interactive markers and interactional markers, writers should develop a balance between face discourse and topic-based discourse (Hyland, 2005b, p. 195).

Discourse analysis is applied for the investigation of the language in use. Journalistic discourse is quite interesting because the writer tries to persuade the readers who may or may not share the writer's point of view (Al-Jarrah, 2011, p. 208). Different kinds of meta-discourse are discussed in different ways but every theory has its merits and demerits. The outlook about things is formulated by the media. Interaction markers are used by the writers to persuade their readers and these interactional markers are analyzed by discourse analysis. This process of analysis projects the voice of the writer, his opinion and how he wants his readers to judge the things and events. Discourse analysis is not concerned with the grammatical aspects of a sentence rather it manipulates different discursive formations (Fairclough, 1992).

Interaction markers are the linguistic devices which are used by the writers to highlight their point of view or to engage the readers into the discourse. A linguistic device that softens the force of a sentence, utterance or statement is called a hedge. Hedges are defined as down graders by Holmes (1995), compromisers by James (1983), weakeners by Brown and Levinson (1987) and softeners by Crystal and Davy (1975). Hedges are utilized as a tool for positive and negative politeness. Many researchers used hedges as softeners and politeness devices. But it is not enough to call these linguistic devices as politeness devices. Hedges have multifunctional roles as they are used differently in different contexts. Boosters are the linguistic devices which make statements more powerful. According to Hyland (2005b), boosters are the words which allow addressers to convey certainty in the statements made. Brown and Levinson (1997) title them as strengtheners. The most common property of boosters is to boost or intensify the positive or negative effect of the utterance (Holmes, 1995). Stress and high volume, modal verbs and pragmatic particles are used as boosters in the spoken and written interactions.

Interaction markers are an important part of discourse as they highlight the knowledge of the writers about anything. Interactional devices help the authors to highlight their authority in the academic world (Rahimivanda, 2014). Different researches have been done in the field of discourse analysis that point out the importance of interaction markers in the journalistic and academic discourses. In all domains of social life theses markers have 
been analyzed. Crismore (1984) investigated interactional markers in text books. Hyland (1998) worked on research articles. On journalistic discourse, Fu and Hyland (2014) worked and defined different categories of these devices. Hedges are the interaction markers and many researchers used hedges softeners and politeness devices. Hedges play multifunctional role as they are used differently in different contexts. They are mentioned in the text or speech to facilitate the reader or listener.

Media has great influence and language used in print and electronic media is a vibrant reflection of social norms and cultural values and ethics. The frequent use of boosters shows the commitment, loyal nature, determination and straightforwardness of female characters in our society. Women utilize the linguistic devices frequently to maintain positive face, showing conformation and agreement. According to Coats (2015) females use hedges to protect listeners' face by the use of hedges and avoid the imposition of ideas or things. Women tend to be polite in their conversation by the use of hedges frequently. They often discuss topics which are sensitive, show personal experiences related to family relations and matters and arouse sentiments and emotions in the addressee. To avoid confrontation, females use hedges, boosters, empty adjectives and tag questions in their talk. For them, opposition or confrontations are hard to bear and against their gentle nature. On the other hand, males always try to convince the addressee by their talk and in the conversation they always try to dominate others.

\subsection{Research Questions}

1) Which are the types of interaction markers are used by male Pakistani journalists in their writings?

2) Which are the types of interaction markers are used by female Pakistani journalists in their writings?

3) Does gender-based difference in the use of interaction markers in the writings of journalists exist?

\section{Literature Review}

The phenomenon that men use language differently from women has been studied for many years. In fact, language is not only a mean of communication but also a source to show your power and supremacy over others. In the past, most of the works on language were related to male language. Many linguists worked on the differences found in the male and females with respect to gender differences. Lakoff (1975) analyzed the language and linguistics code as a source to identify the gender of the speaker or writer. She raised questions: Do women use more adjectives than men? Do women leave their sentences incomplete? Do females have restricted or limited vocabulary than their counterparts.

Recent studies show that the amount of talk by women is three times greater than men. There are two famous models for the study of language and gender: dominance and difference paradigms. According to the Difference Theory, men and women live in culturally different worlds and they adopt distinct behavior of speaking with in the same and single group (Uchida, 1992). In the same culture and place, men and women make different relationships. They seem to belong to separate cultures and places and this is reflected by their language which men and women use within the same social system. By this paradigm bi-cultural conversation seems to be the product of cross-gender production of communication. The Dominancy Theory states that unequal distribution of power defines the cultural and linguistic world of men and women. Men have been the focus of all the activities in the history.

The language used by men was considered as a norm and language used by women was regarded as deviant from the socially accepted norms. Thus, the language used by women was considered to be inferior or non-standard language. Lakoff (1975) argues that there is a typically a language which may be termed as female language. This language is characterized by the use of hedges, intensifiers, tag questions and empty adjectives. The common function of these linguistics devices is to mitigate or weaken the force of utterance in communication. This language is also termed as powerless language because it reflects the feature of weak potions of people in the social setup. This language also predicts the subordinate position of women.

The study of gender raises some basic questions about the link between gender and social patterns. There exists a close link between language and gender and the concept of gender is socially constructed phenomenon (McConnell-Ginet, 1988). The use of language by men and women is deeply rooted in their social roles, practices and power structure. While men talk about politics, sports, economy, international affairs, breaking news, weather condition, religious matters and future planning, women discuss family, home, fashion, cloths, shopping, cooking and education of their children and domestic activities.

Dastjerdi and Shirzad (2010) studied the impact of interaction markers on elementary EFL and advance Iranian students. 94 students of English students from Isfahan University were selected for the research. To check the existing capacity of writing skills of the students, pretest was conducted. The students were divided into elementary, intermediate and advance levels. All groups were instructed about interaction markers in six sessions. 
To check the writing abilities of the students, a post test was conducted. The results highlighted that the intermediate students utilized high frequency of interactional markers as compared to the remaining groups and those students improved their writing skills. Rustipa (2014) analyzed the use of interactional markers by the Indonesian learners. Essays of seven (07) Indonesian students were compared with the British Written Essays (BWE) corpus.

Journalistic discourse is quite interesting because the writer tries to persuade the readers who may or may not share the writer's point of view (Al-Jarrah, 2011, p. 208). The writers present their opinions in the newspapers and utilize interaction markers for persuasiveness. These interactional markers are analyzed by discourse analysis. This process of analysis projects the voice of the writer, his opinion and how he wants his readers to judge the things and events. Eckert and McConnell (1992) presented the idea that gender is the outcome of social interaction and it is prominent in social context and gender is socially constructed phenomenon. There is difference of speech of men and women and this difference is manifested by the language they use. Men use direct, active voice, non-standard and aggressive expressions of language while women's language is considered as polite, standard and emotional. There are differences in the use of language are due to register, style, interaction, culture, norms and language attitudes. Gender based linguistic difference is widely discussed

The field of language and gender is the most important field in the world of sociolinguistics. This subject is popularized in 1999 by the formation of the International Gender Association. Gee and Handford (2013) published the Journal of Language and Gender with the collaboration of this association. Modern technology is used by the researchers to investigate gender differences in language of blogs, social media and e-mails. Herring (2003) studied the instances of gender differences in e-mails and suggested that we can tell the gender of the writer by using the rhetorical strategies.

\section{Theoretical Framework and Research Methodology}

This is quantitative and qualitative research with the application of Hyland's (2005a) model of interaction markers. This model deals with stance and engagement markers (Hyland, 2005a). Stance is textual voice by which the writer projects and conveys his opinions in the text. In other words, it is a technique by which writers hide their involvement and their biasness in the writings. So, stance is writer-oriented approach which diverts audience towards writers' textual voice. Engagement markers are considered as reader-oriented approach. The writer pulls others towards his argument, attracts their attention and leads them towards interpretations (Hyland, 2005a). Stance includes hedges, boosters, self-mentions and attitude markers. Engagement markers include directives, pronouns, questions, personal asides and shared knowledge appeals.

Hyland's (2005a) model of interaction is applied as theoretical framework for the analysis of interaction markers in the journalistic discourse. This model basically deals with stance and engagement markers (Hyland, 2005a). Stance is textual voice by which one projects and conveys his opinions in the text. In other words, it is a technique by which writers hide their involvement and their biasness in the writings. So, stance is writer-oriented approach which diverts audience towards writers' textual voice. Engagement is considered as reader or listener-oriented approach by which the writer pulls others towards his argument, attracts their attention, add them as participants of discourse and leads them towards interpretations (Hyland, 2005a). Stance includes hedges, boosters, self-mentions and attitude markers. Engagement markers include directives, pronouns, questions, personal asides and shared knowledge appeals.

First, quantification of the interaction markers is done and then there is a qualitative analysis of quantified interaction markers. The research methodology includes research design, sample selection, data screening, data encoding, data collection and in the end data presentation.

\subsection{Research Tool}

Antconc 3.2.4w (2011) is the research tool for the corpus analysis. It is a toolkit which is designed by Laurence Anthony for the analysis of corpus (Anthony, 2005). This is an extensive research tool which includes a concordance, words frequency generator, keywords frequency generator, function for cluster analysis and bundle analysis (Antony, 2004). To find out the concordances and functionality of required words, Antconc is used. This research tool only analyzes text notepad files of the required text.

\subsection{Sampling and Population}

The sample taken for corpus is collected from Dawn, Daily Times, The News, The Nation and The Tribune newspapers. Total two hundred (200) articles are analyzed. The corpus is divided into writings written by the male journalists and writings produced by the female journalists. The criteria for sample selection are representation, reputation, accessibility and circulation that are proposed by Nwogu (1997). 


\subsection{Data Collection}

The corpus collected from the selected English newspapers is added in Antconc for the analysis of interaction markers. To see the frequencies of the interaction markers concordance tool is used. Similarly, occurrences of the interaction markers are seen by using the concordance tool. After classifying the he interaction markers in their categories, they are saved in form of text notepad file.

\section{Data Analysis and Findings}

The prime purpose of the analysis to find out gender-based differences in the use of interaction markers in the writings of Pakistani journalists. The analysis is done step wise. First, the interactional markers are illustrated then frequently used interaction markers are mentioned in examples which are found in the corpus. The qualitative analysis of interaction markers explains the criteria of interactional markers according the Hyland's (2005a) model. This analysis is followed by quantitative analysis of the corpus which is presented in the form of tables and graphs. Ten mostly occurring interaction markers with their frequencies are presented in form of tables. The accumulation of interaction markers and final results of male and female journalists are presented in the form of tables and graphs.

\subsection{Interaction Markers in the Writings of Male Journalists}

The corpus analysis highlights different frequencies of stance markers and engagement markers in the data used by the male journalists. There are four categories of stance markers i.e., hedges, boosters, attitude markers and self-mentions. These are presented in the form of tables and graphs. One thousand three hundred and thirteen (1313) hedges are utilized by the male journalists in their writings. The second stance marker boosters are in the corpus with the frequency of two hundred and ninety-five (295). Attitude markers are present in the corpus with the frequency of three hundred and seventy-seven (375). Another stance markers' self-mentions are traced out of the corpus with the frequency of two hundred and twelve (212). Quantitative analysis shows that the Pakistani male journalists effectively use stance markers to present their views explicitly. Engagement markers are described as reader-oriented approach. These engagement markers are present in the corpus with different frequencies which are highlighted in the form of graph. Reader pronouns are engagement markers present in the corpus with the highest frequency of seven hundred (700). Directives are used very frequently by the male journalists and are second most occurring engagement markers with the frequency of four hundred and seventeen (417). The third type of engagement markers are questions in the corpus with the frequency of three hundred and four (304). There are forty-five (45) instances of shared knowledge present in the corpus of male journalists. There are one hundred and three (103) instances of personal asides which are present in the writings of Pakistani male journalists.

Table 1. Ranks and frequencies of interaction markers used by male journalists

\begin{tabular}{ll}
\hline Interaction Markers Used by Male Journalists & Frequencies of Interaction Markers \\
\hline Hedges & 1313 \\
Boosters & 295 \\
Attitude Markers & 375 \\
Self-mentions & 212 \\
Reader Pronouns & 700 \\
Directives & 417 \\
Questions & 304 \\
Shared Knowledge & 45 \\
Personal Asides & 103 \\
\hline
\end{tabular}

\subsection{Interaction Markers in the Writings of Female Journalists}

The results show different frequencies of stance markers and engagement markers in the writings of the female journalists. One thousand three hundred and seventy-seven (1377) hedges are used by the female journalists in their writings. Boosters as stance markers are in the corpus with the frequency of three hundred and eighty (380). Three hundred and forty-five (345) attitude markers are present in the corpus. Another stance markers' self-mentions are traced out of the corpus with the frequency of two hundred and thirty (230). The quantitative analysis shows that Pakistani female journalists use stance markers frequently to present their views explicitly. Engagement markers are described as readers- oriented approach. These engagement markers are present in the corpus with different frequencies which are highlighted in the form of graph. Reader pronouns are present in the corpus with the highest frequency of nine hundred and forty (940). Directives are used very frequently by the 
female journalists with the frequency of three hundred and eighty-nine (389). The third type of engagement markers are questions with the frequency of four hundred and twelve (412). There are twenty-three (23) instances of shared knowledge are present in the corpus of female journalists. There are one hundred and twenty (120) instances of personal asides utilized by the female Pakistani journalists.

Table 2. Ranks and frequencies of interaction markers used by female journalists

\begin{tabular}{ll}
\hline Interaction Markers Used by Male Journalists & Frequencies of Interaction Markers \\
\hline Hedges & 1377 \\
Boosters & 380 \\
Attitude Markers & 345 \\
Self-mentions & 230 \\
Reader Pronouns & 940 \\
Directives & 389 \\
Questions & 412 \\
Shared Knowledge & 23 \\
Personal Asides & 120 \\
\hline
\end{tabular}

\subsection{Gender Based Difference in the Use of Interaction Markers by Male and Female Journalists}

To find the gender-based difference in the use of interaction markers in the writing of male and female journalists, null hypothesis is applied and this hypothesis is tested with the help of Chi-square Independence test. The results show that in the corpus of one lac (100000) words, three thousand seven hundred and sixty-four (3764) interaction markers are used by the male Pakistani journalists. Similarly, four thousand two hundred and sixteen (4216) interaction markers are traced out of the corpus of one lac words (100000) corpus which is built by the writings of twenty (20) female Pakistani journalists. To explain the gender-based differences, a comparative analysis of the results is done. To find the gender-based difference in the use of interaction markers in the writing of male and female journalists, null hypothesis is applied and this hypothesis is tested with the help of Chi-square Independence test. Null Hypothesis $\left(\mathrm{H}_{0}\right)$ : The hypothesis states that there exists statistically no significant gender-based difference in the use of interaction markers in the writings of male and female Pakistani journalists. This hypothesis is challenged by the researcher in the form of alternative hypothesis that there is statistically a significant gender-based difference in the use interaction markers in the writings of Pakistani journalists.

Alternative Hypothesis $\left(\mathrm{H}_{1}\right)$ : There is statistically a significant gender-based difference in the use of interaction markers in the writings of Pakistani journalists. Alternative hypothesis is formulated to reject the null hypothesis by the research. The Chi-Square Independence test is utilized to investigate whether there exists or not gender based difference in the use of interaction markers in the writings of Pakistani male and female journalists.

Table 3. Observed values and expected values of stance markers and engagement markers

\begin{tabular}{llll}
\hline & Stance Markers & Engagement Markers & Marginal Row Totals \\
\hline Male & $2195(2135.29)$ & $1569(1628.71)$ & 3764 \\
Female & $2332(2391.71)$ & $1884(1824.29)$ & 4216 \\
Marginal Column Totals & 4527 & 3453 & 7980 (Grand Total) \\
\hline
\end{tabular}

The chi-square statistic is 7.3033. The $p$-value is .006883 . This result is significant at $p<.05$.

To find out whether the difference is significant or not Chi-Square test is run.

Results: $X^{2}=7.3033$

The probability $p$ value is .006883 and this result is significant at $\mathrm{p}<.05$.

The p-value (.006883) is less than the significance level (0.05) therefore null hypothesis is rejected. It is evident from the Chi-Square test results that there is a relationship between gender and the use of interaction markers.

\subsection{Comparative Analysis of Interaction Markers Used by the Pakistani Male and Female Journalists}

The variation in the use of these lexical devices is highlighted by the comparative analysis. The results show that hedges are the interaction markers which are used with high frequency by the male and female journalists in the journalistic discourse. The second most frequently used interaction marker is reader pronouns. There is a broad 
difference of four hundred and fifty-two (452) interaction markers in the writings of Pakistani male and female journalists.

Table 4. Comparative analysis of interaction markers used by male and female journalists

\begin{tabular}{llll}
\hline Interaction Markers & Used by Male Journalists & Used by Female Journalists & Difference \\
\hline Hedges & 1313 & 1377 & 64 \\
Boosters & 295 & 380 & 85 \\
Attitude Markers & 375 & 345 & 30 \\
Self-mentions & 212 & 230 & 18 \\
Reader Pronouns & 700 & 940 & 240 \\
Directives & 417 & 389 & 28 \\
Questions & 304 & 412 & 108 \\
Shared Knowledge & 45 & 23 & 22 \\
Personal Asides & 103 & 120 & 17 \\
Total & 3764 & 4216 & 452 \\
\hline
\end{tabular}

Table 4 explicitly highlights the differences in the use of interaction markers by the male and female journalists. The frequencies of attitude markers, directives and shared knowledge references are higher in the corpus of male journalists than the female journalists.

\section{Conclusion}

The findings of this corpus-based research highlight many important facts. The purpose of the research study is to explore gender-based differences in the use of interaction markers in the writings of Pakistani male and female journalists. The corpus analysis shows a major variation of frequencies in the use of interaction markers by the journalists. The quantification of the corpus reveals that there is a broad difference in the use of interaction markers by the male and female journalists. Female journalists frequently used interaction markers in their writings when compared to male journalists.

The accumulative results show that three thousand seven hundred and sixty-four interaction markers are used by the male journalists and four thousand two hundred and sixteen lexical devices are employed by the female journalists. Interaction markers as linguistic devices can modify the force of the utterances. These findings are the base to define the language variation in the form of difference in the use of interaction markers by the Pakistani male and female journalists. The results of the quantitative analysis of the corpus show that female journalists use interaction markers in a greater number as compared to male journalists. These devices have a positive effect and enable the writers to maintain writer-reader relationship and minimize the chances of confrontation and opposition. The higher ratio of interaction markers in the journalistic discourse shows confident nature of female journalists and it is the reflection of great commitment about the information supplied. The proper use of these interaction devices also shows mastery of language on the part of the writer. The frequent use of interaction markers by the female journalist is the indication of different psychology of both the genders.

It could be deciphered that female journalists prefer to use hedges, boosters and self-mentions frequently to project their identity. Engagement markers, reader pronouns, questions, and personal asides have higher frequency in the writings of female journalists than the male journalists. Directives and shared knowledge references are greater in the writings of male journalists as compared to female journalists. The study suggests that females are more polite, caring and supportive than males. Female speakers keep in mind the effect of words on others while males do not think about the effect of their harsh words on others. The extensive use of interaction markers by the female journalists highlights that the writings of female journalist are more convincing, decorative ones and they try to engage their readers into the discourse by the use of interaction markers in their writings. These interaction devices play an important role of the journalistic discourse. The writers express their identity and stance through these interaction strategies in their writings. These interaction markers are used by the writers to withhold commitment, emphasis certainty, express their positive or negative attitude to the proposition and engage the reader in the discourse. The study depicts that gender differences in the use of interaction markers is an important area in the field of discourse analysis. There are many factors which work for the segregation of male language from female language and media is a vibrant source for the exhibition of social norms and values. 


\section{References}

Adel, A. (2006). Metadiscourse in L1 and L2 English. Philadelphia: John Benjamins. https://doi.org/10.1075/scl.24

Al-Jarrah, M. (2011). Arabic newspapers discourse: Rhetorical features, discourse markers, strategies and organization. Damascus University Journal, 27(3), 207-235.

Coates, J. (2015). Women, men and language: A sociolinguistic account of gender differences in language. Routledge. https://doi.org/10.4324/9781315645612

Crismore, A. (1984). The rhetoric of textbooks: Metadiscourse. Journal of Curriculum Studies, 16(3), 279-296. https://doi.org/10.1080/0022027840160306

Crystal, D., \& Davy, D. (1975). Advanced Conversational English (vol. 1). Longman Publishing Group.

Dastjerdi, H. V., \& Shirzad, M. (2010). The impact of explicit instruction ofmetadiscourse markers on EFL learners writing performance. The Journal of Teaching Language Skills, 2(2), 155-174.

Drass, K. A. (1986). The effect of gender identity on conversation. Social Psychology Quarterly, 294-301. https://doi.org/10.2307/2786768

Eckert, P., \& McConnell-Ginet, S. (1992). Think practically and look locally: Language and gender as community-based practice. Annual Review of Anthropology, 21(1), 461-488. https://doi.org/10.1146/annurev.an.21.100192.002333

Fairclough, N. (1992). Discourse and text: Linguistic and intertextual analysis within discourse analysis. Discourse \& Society, 3(2), 193-217. https://doi.org/10.1177/0957926592003002004

Gee, J. P., \& Handford, M. (Eds.). (2013). The Routledge handbook of discourse analysis. Routledge. https://doi.org/10.4324/9780203809068

Herring, S. C. (2003). Gender and power in on-line communication. The handbook of Language and Gender, 202-228. https://doi.org/10.1002/9780470756942.ch9

Holmes, J. (1995). Men, women and politeness. London: Longman.

Huddleston, R., \& Pullum, G. K. (2005). A student's introduction to English grammar. Cambridge University Press. https://doi.org/10.1017/CBO9780511815515

Hyland, K. (1998a). Persuasion and context: The pragmatics of academic metadiscourse. Journal of Pragmatics, 30, 437-455. https://doi.org/10.1016/S0378-2166(98)00009-5

Hyland, K. (1999). Talking to students: Metadiscourse in introductory course books. English for Specific Purposes, 18(1), 3-26. https://doi.org/10.1016/S0889-4906(97)00025-2

Hyland, K (2005a). Metadiscourse: Mapping Interactions in Academic Writing. University of London, UK.

Hyland, K. (2005b). Metadiscourse: Exploring Interaction in Writing. London: Continuum.

Hyland, K., \& Tse, P. (2004c). Metadiscourse in academic writing: a reappraisal. Applied Linguistics, 25, 156177.

Lakoff, R. (1973). Language and woman's place. Language in Society, 2(1), 45-79. https://doi.org/10.1017/S0047404500000051

Levinson, P., Brown, P., Levinson, S. C., \& Levinson, S. C. (1987). Politeness: Some universals in language usage (Vol. 4). Cambridge university press.

McConnell-Ginet, S. (1988). Language and Gender. Linguistics: the Cambridge Survey, 4, 75-99.

Nwogu, K. N. (1997). The medical research paper: Structure and functions. English for Specific Purposes, 16(2), 119-138. https://doi.org/10.1016/S0889-4906(97)85388-4

Rahimivand, M., \& Kuhi, D. (2014). An exploration of discoursal construction of identity in academic Writing. Procedia-Social and Behavioral Sciences, 98, 1492-1501. https://doi.org/10.1016/j.sbspro.2014.03.570

Rustipa, K. (2014). Metadiscourse in Indonesian EFL learners' persuasive texts: A case study at English department, UNISBANK. International Journal of English Linguistics, 4(1), 44. https://doi.org/10.5539/ijel.v4n1p44

Tannen, D. (1990). You just don't understand: Women and men in communication (p. 42). New York: William Morrow. 
Uchida, A. (1992). When "difference" is "dominance": A critique of the "anti-power-based" cultural approach to sex differences. Language in Society, 21(4), 547-568. https://doi.org/10.1017/S0047404500015724

Xu, H. (2001). Metadiscourse: A cross-cultural perspective. Nanjing: Southeast University Press.

\section{Copyrights}

Copyright for this article is retained by the author, with first publication rights granted to the journal.

This is an open-access article distributed under the terms and conditions of the Creative Commons Attribution license (http://creativecommons.org/licenses/by/4.0/). 